\title{
HUBUNGAN DINAMIKA KELOMPOK DENGAN PRODUKTIVITAS PETERNAK DOMBA DI PAGUYUBAN AL- AWWALIYAH, PASIR WANGI, GARUT
}

\author{
Inayatullah, Ujang Maman* dan Iwan Aminudin
}

\begin{abstract}
ABSTRAK
Penelitian ini bertujuan untuk mengetahui bagaimana kondisi kelompok dinamis, produktivitas petani, dan hubungan antara dinamika kelompok dan produktivitas peternak KTN membantu Komunitas Al-Awwaliyah, Garut, Jawa Barat. Metode Rank Spearman digunakan untuk menganalisis data. Hasil uji statistik menunjukkan bahwa tujuan dari kelompok, struktur kelompok, fungsi tugas kelompok, pengembangan dan pemeliharaan kelompok, suasana kelompok, dan tekanan teman sebaya berhubungan dengan produktivitas peternak. Dari enam indikator dinamika kelompok, indikator lingkungan kelompok menempati peringkat tertinggi dengan jumlah 95,6\%. Selain itu, dari tiga indikator produktivitas peternak, indikator kepercayaan diri tinggi menempati peringkat tertinggi dengan jumlah $84,4 \%$.
\end{abstract}

Kata kunci: peternak, produktivitas, dinamika kelompok, KTN, Rank Spearman

\section{ABSTRACT}

This study aims to find out how the group dynamic conditions, the productivity offarmers, and the relationship between group dynamics and productivities of breeders KTN assisted in Al-Awwaliyah Community, Garut, West Java. The Spearman Rank was employed to analyze the data. Rank Spearman statistical test results showed that the purpose of the group, the group structure, the function of the task group, the development and the maintenance of the group, the group atmosphere, and the peer pressure associated with the productivity of breeders. Of the six indicators of group dynamics, group environment indicators occupy the highest ratings in the amount of $95.6 \%$. Besides, of the three indicators of the productivity of breeders, high confidence indicators occupy the highest ratings in the amount of $84.4 \%$.

Keywords: breeders, productivity, group dynamic, KTN, Rank Spearman

\section{PENDAHULUAN}

Kelompok tani ternak merupakan kumpulan peternak yang tumbuh berdasarkan keakraban dan keserasian, serta kesamaan kepentingan dalam memanfaatkan sumber daya yang ada untuk bekerja sama mencapai kesejahteraan anggotanya. Kelompok tani ternak tidak akan berfungsi sesuai yang diharapkan jika kurangnya pembinaan dan pelatihan dari para penyuluh atau pendamping peternak. Seiring dengan perkembangan, maka dibentuklah kelompok-kelompok tani ternak dampingan Kampoeng Ternak Nusantara (KTN) agar peternak lebih aktif dan berperan dalam berbagai kegiatan. Begitu pula dengan kelompok tani ternak yang ada di Paguyuban AlAwwaliyah. Tersirat juga didalamnya proses pendampingan yang terjadi dalam 
mewujudkan dan mempertahankan kelompok, terutama dalam membimbing dan mengarahkan para anggota kelompok dalam mengambil keputusan dan hal-hal yang berkaitan dengan program yang diharapkan bisa meningkatkan produktivitas peternaknya, di mana bimbingan dan arahan dari pendamping tersebut juga diharapkan dapat mempertahankan bahkan mencapai keefektifan dari kelompok.

Kelompok tani ternak ini diharapkan memiliki peran yang penting bagi para anggota kelompok sebagai tempat ataupun wadah bertukar informasi agar kedepannya produktivitas peternak yang ada di kelompok tani ternak Paguyuban AlAwwaliyah diharapkan bisa meningkat. Melalui kelompok tani ternak yang ada diPaguyuban Al-Awwaliyah ini informasi yang berkaitan untuk meningkatkan produktivitas peternaknya akan dapat diperoleh, serta inovasi baru dan teknologi baru dalam kegiatan beternak juga mudah diketahui untuk diterapkan melalui kegiatan penyuluhan yang teratur dan terencana. Dengan bergabungnya para peternak ke dalam kelompok tani ternak dampingan Kampoeng Ternak Nusantara (KTN) ini diharapkan produktivitas peternak kelompok di paguyuban dapat meningkat. Oleh karena itu, untuk mengetahui dinamis atau tidaknya suatu kelompok tani ternak bisa diukur dari tujuan kelompok, struktur kelompok, fungsi tugas kelompok, pengembangan dan pemeliharaan kelompok, suasanan kelompok, dan tekanan kelompok, sehingga nantinya kelompok ternak tersebut bisa diketahui apakah dinamika dalam kelompoknya tinggi, sedang, ataupun rendah.

Namun hal tersebut belum dapat dipastikan maka diperlukan adanya penelitian dan pengamatan lebih dalam mengenai hubungan dinamika kelompok dengan produktivitas peternak di Paguyuban Al-Awwaliyah, Pasir Wangi. Beranjak dari uraian di atas, maka penulis tertarik untuk meneliti tentang "Hubungan Dinamika Kelompok Dengan Produktivitas Peternak Domba di Paguyuban AlAwwaliyah, Pasir Wangi, Garut" dengan memperhatikan tingkat dinamika kelompok dengan produktivitas peternak di Paguyuban Al-Awwaliyah.

\section{METODE PENELITIAN}

\section{Lokasi dan Waktu Penelitian}

Penelitian ini dilaksanakan di Paguyuban Al-Awwaliyah yang berlokasi di Desa Pasir Wangi, Kecamatan Drajat, Kabupaten Garut. Peneliti melakukan penelitian di lokasi tersebut karena jumlah populasi yang mencukupi yakni 80 orang, serta anggota kelompok ternak berstatus aktif sehingga memudahkan peneliti untuk melakukan penelitian. Adapun waktu pelaksanaan penelitian dimulai pada bulan November sampai dengan bulan Desember 2014.

\section{Populasi dan Sampel}

Populasi adalah wilayah generalisasi yang terdiri dari obyek atau subyek yang mempunyai kualitas dan karakteristik tertentu yang ditetapkan oleh peneliti untuk dipelajari dan kemudian ditarik kesimpulan. Populasi juga bukan sekedar jumlah yang terdapat pada obyek/subyek yang dipelajari, tetapi meliputi seluruh karakteristik/sifat yang dimiliki oleh subyek/obyek tersebut (Sugiyono, 2009).

Populasi pada penelitian ini adalah anggota kelompok ternak Paguyuban Al-Awwaliyah. Berdasarkan data yang diperoleh, jumlah peternak yang ada di Paguyuban AL-Awwaliyah sejumlah 80 orang. Sampel adalah bagian dari jumlah populasi yang 
mempunyai ciri-ciri atau keadaan tertentu yang akan diteliti tersebut. Apabila populasi besar, dan peneliti tidak dapat mempelajari semua yang ada padapopulasi, dikarenakan keterbatasan dana, tenaga dan waktu, maka peneliti dapat menggunakan sampel yang diambil dari populasi itu (Sugiyono, 2009).

\begin{tabular}{lrr}
\multicolumn{2}{c}{ Adapun teknik pengambilan } \\
sampel yang dipilih adalah \\
nonprobability & sampling. Teknik
\end{tabular}
pengambilan sampel dengan tidak memberikan kesempatan yang sama bagi setiap unsur populasi yang akan dipilih menjadi anggota sampel (Pabundu, 2006). Teknik nonprobability sampling yang digunakan adalah accidental sampling .

Sampel aksidental adalah teknik penentuan sampel berdasarkan kebetulan, yaitu siapa saja yang kebetulan bertemu dengan peneliti dapat digunakan sebagai sampel (Sugiono, 2009). Penelitian ini memakai teknik sampling aksidental dikarenakan keadaan yang ada di tempat penelitian yang tidak memungkinkan, yang mana kondisi alam dan kelompok ternaknya berada di lokasi yang berjauhan dan menyebar sehingga sulit bagi peneliti untuk bisa mendatangi lokasi kelompok yang sangat jauh dari tempat tinggal. Responden yang diambil oleh peneliti adalah responden yang dapat ditemui dan berjumlah 45 orang.

\section{Data dan Instrumentasi \\ Data}

Sesuai dengan variabel bebas dan variabel terikat, peneliti mengumpulkan data mengenai:

1. Karakteristik peternak, meliputi: umur, masa pendidikan, pengalaman beternak, dengan definisi operasional sebagai berikut: a. Umur merupakan usia hidup responden sejak lahir sampai ulang tahun terdekat sebelum waktu pengumpulan data penelitian ini, diukur dalam satuan tahun.

b. Masa pendidikan merupakan lamanya responden menempuh jalur pendidikan terakhir, dihitung dalam satuan tahun.

c. Pengalaman beternak merupakan waktu dan lamanya responden melakukan usaha beternak hingga saat pengumpulan data penelitian ini, diukur dalam satuan tahun.

2. Dinamika kelompok, meliputi: tujuan kelompok, struktur kelompok, fungsi tugas kelompok, pengembangan dan pemeliharaan kelompok, suasana kelompok, tekanan kelompok, dengan definisi operasional sebagai berikut:

a. Tujuan kelompok merupakan segala sesuatu yang akan dicapai oleh kelompok dan harus relevan dengan tujuan anggota serta diketahui oleh semua anggotannya, diukur dengan membuat skor berdasarkan tiga jenjang kemampuan.

b. Struktur kelompok merupakan bentuk hubungan antara individu-individu dalam kelompok sesuai posisi dan peranan masingmasing, diukur dengan membuat skor berdasarkan tiga jenjang kemampuan.

c. Fungsi tugas kelompok merupakan segala kegiatan yang harus dilakukan kelompok dalam rangka mencapai tujuan, diukur 
dengan membuat skor berdasarkan tiga jenjang kemampuan.

d. Pengembangan

dan pemeliharaan kelompok merupakan sejumlah hal yang harus tetap ada dan terpelihara dalam kelompok, diukur dengan membuat skor berdasarkan tiga jenjang kemampuan.

e. Suasana kelompok merupakan suasana untuk menimbulkan gairah kerja yang menyangkut segi sikap dan perasaan anggota, diukur dengan membuat skor berdasarkan tiga jenjang kemampuan.

f. Tekanan kelompok merupakan suatu keadaan yang menimbulkan 'tegangan' pada kelompok untuk menumbuhkan dorongan berbuat sesuatu demi tercapainya tujuan kelompok, diukur dengan membuat skor berdasarkan tiga jenjang kemampuan.

3. Produktivitas peternak, meliputi: kemampuan membaca peluang, berani menghadapi resiko, dan pemanfaatan informasi, dengan definisi operasional sebagai berikut:

Kemampuan membaca
peluang merupakan ruang
gerak, baik yang konkret
maupun yang abstrak, yang
memberikan kemungkinan
bagi suatu kegiatan untuk
memanfaatkan kesempatan
dalam usaha mencapai
tujuan, serta berusaha
mencari jalan keluar dari
setiap masalah, diukur
dengan membuat skor

berdasarkan tiga jenjang kemampuan.

b. Kepercayaan diri yang tinggi merupakan sifat selalu yakin dengan kemampuan dan gagasan sendiri, tidak bergantung pada orang lain dan tidak mudah putus asa, diukur dengan membuat skor berdasarkan tiga jenjang kemampuan.

c. Pemanfaatan informasi merupakan data yang telah diolah menjadi bentuk yang memiliki arti bagi si penerima dan bermanfaat bagi pengambilan keputusan saat ini atau mendatang, diukur dengan membuat skor berdasarkan tiga jenjang kemampuan.

\section{Instrumentasi}

Pengumpulan data dilakukan dengan menggunakan berbagai teknik pengumpulan data (instrumentasi) sebagai berikut:

1. Pengumpulan data mengenai karakteristik peternak dilakukan dengan membuat kuesioner yang menanyakan tentang umur, masa pendidikan, pengalaman beternak.

2. Pengukuran data mengenai dinamika kelompok dilakukan dengan membuat kuesioner mengenai tujuan kelompok, struktur kelompok, fungsi tugas kelompok, pengembangan dan pemeliharaan kelompok, suasana kelompok, dan tekanan kelompok.

3. Pengukuran data mengenai produktivitas yang dimiliki peternak dilakukan dengan membuat kuesioner mengenai sifat yang dapat menghasilkan produktivitas yaitu kemampuan 


membaca peluang,
menghadapi resiko,
pemanfaatan informasi.

\section{Sumber Data}

Sumber data yang digunakan pada penelitian ini adalah dengan menggunakan data primer dan data skunder. Sumber data primer adalah sumber data yang secara langsung memberikan data kepada pengumpul data (Sugiyono, 2009). Data primerpenelitian ini berupa catatan hasil wawancara yang diperoleh melalui wawancara pada kelompok ternak Paguyubban Al-Awwaliyah. Selain itu, penulis juga melakukan pengumpulan sejumlah pernyataan berupa kuesioner yang diberikan langsung kepada responden di kelompok ternak Paguyubban AlAwwaliyah. Sedangakan data sekunder berasal dari berkas-berkas atau data yang berasal dari Paguyuban, literatur dan studi pustaka.

\section{Pengukuran Variabel Penelitian}

Skala pengukuran yang digunakan dalam penelitian ini adalah modifikasi skala Likert, yaitu dari 1 sampai 3. Skala pengukuran untuk variabel DinamikaKelompok (X) dan Produktivitas Peternak (Y) diukur dan disesuaikan dengan materi penelitian.

\section{Validitas dan Reliabilitas Instrumen \\ Validitas}

Salah satu masalah dalam penelitian adalah cara memperoleh data yang akurat dan objektif. Hal ini menjadi sangat penting sebab kesimpulan yang di ambil hanya akan dapat dipercaya bila didasarkan pada data yang akurat. Untuk itu penelitian ini perlu diketahui seberapa tinggi reabilitas dan validitas alat ukur (instrumen) yang digunakan.Sesuai dengan metode penelitian yang digunakan, maka dalam penellitian ini untuk melakukan analisis data yang bersifat kuantitatif maka digunakan alat analisis statistik. Rancangan analisis merupakan langkah-langkah yang dilakukan dalam menganalisis data. Sebuah instrumen dinyatakan valid apabila mengungkapkan data dari variabel yang diteliti secara tepat. Tinggi rendahnya validitas instrument menunjukkan sejauh mana data yang terkumpul tidak menyimpang darigambaran tentang variabel yang dimaksud. Untuk menguji korelasi antara masingmasing pernyataan yang terdapat pada kuesioner, maka digunakan rumus korelasi Product moment

$r_{x y}=\frac{N\left(\sum X Y\right)-\left(\sum X \sum Y\right)}{\sqrt{\left.\left\{\left(N \sum X^{2}\right)-\left(\sum X^{2}\right)\right\}\left(N \sum Y^{2}\right)-\left(\sum Y^{2}\right)\right\}}}$

Keterangan:

rxy $=$ Angka indeks korelasi " $\mathrm{r}$ " Product moment

$\mathrm{N}=$ Number of cases atau jumlah data

$\sum X Y=$ Jumlah hasil perkalian antara skor XY

$\sum \mathrm{X}=$ Jumlah skor dalam sebaran $\mathrm{X}$ $\sum \mathrm{Y}=$ Jumlah skor dalam sebaran

$\mathrm{X}^{2}=$ Jumlah skor yang dikuadratkan dalam selebaran $X$

$\mathrm{Y}^{2}=$ Jumlah skor yang dikuadratkan dalam selebaran Y

\section{Reliabilitas}

Menurut Sugiyono (2009),

Reliabilitas instrumen adalah instrument yang bila digunakan beberapa kali untuk mengukur objek yang sama, akan menghasilkan data yang sama. Jadi uji reliabilitas suatu alat ukur untuk mengukur suatu kuesioner agar 
kuesioner yang disusun oleh peneliti dapat dikatakan reliabel (dapat diandalkan).

$$
r_{11}=\left[\frac{k}{(k-1)}\right]\left[1-\frac{\sum \sigma_{b}^{2}}{\sigma_{t}^{2}}\right]
$$

Keterangan:

r 11 = reliabilitas yang dicari

$\mathrm{n}$ = Jumlah item pertanyaan yang di uji

$\mathrm{k}$ = banyaknya butir pertanyaan atau banyaknya soal

$\sum \mathrm{s}$ b2 $=$ jumlah varians skor tiap-tiap item

$\mathrm{s} \mathrm{t} 2=$ varians tot

Jika nilai alpha $>0,6$ artinya reliabilitas mencukupi (sufficient reliability) sementara jika alpha $>0,80$ ini mensugestikan seluruh item reliabel dan seluruh tes

secara konsisten secara internal karena memiliki reliabilitas yang kuat atau dapat dirincikan sebagai berikut:

a. Jika alpha > 0,90 maka reliabilitas sempurna

b. Jika alpha antara $0,70-0,90$ maka reliabilitas tinggi

c. Jika alpha antara $0,50-0,70$ maka reliabilitas moderat

d. Jika alpha $<0,50$ maka reliabilitas rendah

\section{Metode Pengumpulan Data}

Teknik pada penelitian ini adalah dengan menggunakan cara memberikan kuesioner kepada responden yang tergabung dalam kelompok Paguyuban Al-Awwaliyah yang ada di Pasir Wangi. Metode kuesioner adalah teknik pengumpulan data yang dilakukan dengan cara memberikan pernyataan/pertanyaan tertulis kepada responden untuk dijawab. Kuesioner merupakan teknik pengumpulan data yang efisien apabila peneliti mengerti dengan pasti variabel yang akan diukur dan mengerti apa yang bisa diharapkan dari responden (Sugiyono, 2009). Untuk memperoleh data yang benar diperlukan alat pengumpul data yang valid dan reliabel. Oleh karena itu, kuesioner yang dijadikan instrumen penelitian telah diuji validitas dan realibilitasnya.

\section{Penyajian Data}

Tahap penyajian data pertama kali yaitu, data ditabulasikan dengan menggunakan bantuan program excel, setelah ditabulasikan selanjutnya data disusunmulai dari skor terkecil sampai dengan skor terbesar. Kemudian data yang sudah di susun tersebut dipindahkan ke dalam program SPSS versi 21 untuk diolah lebih dalam lagi agar nantinya diperoleh hasil apakah antara dinamika kelompok dan produktivitas peternak memiliki hubungan yang tinggi, sedang, ataupun rendah.

\section{Metode Analisis Data}

Teknik analisis data yang digunakan adalah dengan mengukur hubungan variabel bebas dan variabel terikat. Dalam penelitian ini, analisis data dilakukan untuk mengetahui apakah terdapat pengaruh antara hubungan dinamika kelompok dengan produktivitas, maka digunakan metode korelasi rank Spearman

\section{Analisis Korelasi Rank Spearman}

Data dan Informasi yang telah terkumpul baik dari tingkat individu, kelompok, dan responden yang terpilih, kemudian diolah dan dianalisis dengan prosedur sebagai berikut: Analisis deskriptif, yaitu untuk mendeskripsikan karakteristik tentang peubah yang diamati dan Analisis statistik non parametrik, yaitu untuk mengetahui nilai hubungan antara dinamika kelompok dengan produktivitas usaha ternak. Anlisis ini menggunakan program SPSS (Statistical Package for Sosial Science). Menurut Dergibson (2006) koefisien korelasi Rank Spearman digunakan 
untuk mengetahui derajat keeratan dua variabel yang memiliki skala pengukuran minimal ordinal. Adapun rumus korelasi rank spearman adalah sebagai berikut:

$$
r s=1-\frac{6 \sum d^{2}}{n\left(n^{2}-1\right)}
$$

Keterangan:

rs $=$ Koefisien korelasi Spearman

$\sum \mathrm{d} 2=$ Total kuadrat selisih antara ranking

$\mathrm{N}$ = Jumlah sampel penelitian

\section{Frekuensi}

Untuk melihat tanggapan responden terhadap variabel Dinamika Kelompok dan Produktivitas Peternak, penulis menggunakan analisis deskriptif dengan melihat jawaban responden. Pengukuran dilakukan dengan cara menghitung skor jawaban responden terhadap elemen-elemen tersebut, dengan ketentuan sebagai berikut:

Interval $=\frac{\text { Skor } \text { Tertinggi-Skor } \text { Terendah }}{\text { Jumlah } \text { Kelas }}$

\section{HASIL DAN PEMBAHASAN}

\section{Karakteristik Responden}

Karakteristik responden merupakan salah satu faktor internal yang dapat menjelaskan perbedaan dari masingmasing responden yang ada di tempat penelitian. Adapun karakteristik responden yang diambil dalam penelitian ini meliputi usia, jenis kelamin, dan tingkat pendidikan.

\section{Usia}

Distribusi responden menurut usia pada penelitian ini akan memberikan gambaran usia responden di Paguyuban Al-Awwaliyah di Pasir Wangi, distribusi responden menurut usia, maka dari 45 orang responden dalam penelitian ini usia yang mendominasi adalah responden dengan usia 31-40 tahun, hal ini didapat karena saat peneliti mengambil sampel, responden yang paling sering ditemui adalah responden yang berusia 31-40 dikarenakan pada usia tersebut para peternak sedang berada dimasa-masa usia yangproduktif serta kondisi fisik yang masih bugar dalam beternak sehingga sanggup menerima informasi yang diberikan atau didapat dengan baik.

\section{Jenis kelamin}

Distribusi responden menurut jenis kelamin pada penelitian ini akan memberikan gambaran jenis kelamin responden di Paguyuban Al-Awwaliyah di Pasir Wangi.

\section{Tingkat Pendidikan}

Distribusi responden menurut tingkat pendidikan pada penelitian ini akan memberikan gambaran tingkat pendidikan resonden di Paguyuban AlAwwaliyah di Pasir Wangi.distribusi responden menurut tingkat pendidikan, nampak bahwa sebagian besar responden yang mengisi kuesioner ini lebih banyak memiliki jenjang pendidikan selama 4-6 tahun yakni $71,1 \%$. Sehingga dapat disimpulkan bahwa rata-rata tingkat pendidikan terakhir anggota Paguyuban AlAwwaliyah adalah responden yang mempunyai tingkat pendidikan selama 4-6 tahun ini disebabkan kurangnya sosialisasi akan pentingnya pendidikan sehingga banyak diantaranya lebih mementingkan mencari uang dibanding sekolah, serta ketidakmampuan untuk melanjutkan pendidikan di sekolah yang berdampak pada banyak yang putus sekolah diakibatkan kekurangan biaya. 


\section{Pengalaman Beternak}

Distribusi responden berdasarkan pengalaman beternak pada penelitian ini akan memberikan gambaran pengalaman beternak yang dimiliki responden sebelum bergabung dengan Paguyuban Al-Awwaliyah, Garut.dari 34 responden yang memiliki pengalaman beternak sebelum mereka bergabung ke paguyuban. Sehingga dapat disimpulkan bahwa responden yang ditemui oleh peneliti dari total jumlah 45 responden terdapat 34 responden yang sudah memiliki pengalaman beternak sebelum mereka bergabung dengan Paguyuban, dan rata-rata pengalaman beternak yang didapatkan berasal dari orang tua mereka yang sebelumnya telah melakukan kegiatan beternak secara turun-temurun.

\section{Dinamika Kelompok}

Distribusi responden berdasarkan Dinamika Kelompok pada penelitian ini akan memberikan gambaran ada atau tidaknya kedinamisan dalam kelompok darimasing-masing responden yang ada di Paguyuban Al-Awwaliyah.

Distribusi responden berdasarkan dinamika kelompok bisa dilihat jumlah responden terbanyak didominasi kategori dinamis yaitu sebanyak 23 responden, kategori dinamis, kurang dinamis, dan tidak dinamis didapat dari hasil perhitungan skor tertinggi (60) dikurangi skor terendah (53) kemudian dibagi jumlah kelasnya (3), dari perhitungan tersebut didapat kategori dinamis (59-60), kurang dinamis (5658), dan tidak dinamis (53-55). Sehingga dapat disimpulkan bahwa hasil distribusi responden berdasarkan dinamika kelompok didominasi oleh responden yang dinamis yaitu sebanyak 23 responden dengan persentase sebesar $51,1 \%$, di mana responden yang memiliki kedinamisan adalah responden yang menganggap kelompok ternak sebagai keluarga sehingga merasa merasa nyaman ketika berada di lingkungan kelompok ternak di Paguyuban Al-Awwaliyah.

\section{Unsur-unsur Dinamika Kelompok}

Nilai tertinggi diperoleh dimensi suasana kelompok dengan persentase sebesar $95,6 \%$ yang memiliki tiga indikator yaitu (a) hubungan antar anggota yang harmonis, (b) kebebasan berpartisipasi, (c) lingkungan fisik, artinya semakin baik atau nyaman suasana dalam kelompok, baik dari segi hubungan antar anggota, kebebasan berpartisipasi maupun lingkungan fisiknya, maka tingkat kedinamisan kelompok akan semakin tinggi. Dan nilai paling rendah diperoleh dimensi tekanan kelompok dengan persentase sebesar $51,1 \%$.

\section{Produktivitas Peternak}

Distribusi responden berdasarkan produktivitas peternak pada penelitian ini akan memberikan gambaran tinggi atau rendahnya tingkat produktivitas peternak yang dimiliki dalam kelompok dari masing-masing responden yang ada di Paguyuban AlAwwaliyah.

Dari 45 responden yang diteliti didapatkan hasil dari distribusi responden berdasarkan produkivitas peternak bisa dilihat jumlah respondenterbanyak didominasi kategori produktivitas tinggi yaitu sebanyak 29 responden, kategori Tinggi, dan sedang didapat dari hasil perhitungan skor tertinggi (24) dikurangi skor terendah (19) kemudian dibagi jumlah kelasnya (3), dari perhitungan tersebut didapat kategori tinggi (22-24), dan sedang (1921). Sehingga dapat disimpulkan bahwa hasil distribusi responden berdasarkan produktivitas Peternak didominasi oleh responden yang memiliki tingkat produktivitas tinggi yaitu sebanyak 29 responden dengan persentase sebesar $64,4 \%$ dan untuk kategori responden 
dengan produktivitas sedang sebanyak 16 responden dengan persentase sebesar $35,6 \%$, dimana respoden yang memiliki produktivitas tinggi adalah responden rata-rata masih memiliki usia yang produktiv, sehingga mereka sanggup menerima dan menyerap dengan baik segala sesuatu informasi yang berhubungan dalam meningkatkan ternak yang dimiliki.

\section{Unsur-unsur Produktivitas Peternak}

Berdasarkan hasil analisa dan interpretasi data-data sebelumnya, maka dapat dilihat unsur-unsur produktivitas peternak sebagaimana tertera pada tabel 5.8, Berdasarkan jawaban responden pada tabel tersebut di atas, dari tiga unsur produktivitas peternak yaitu (a) kemampuan membaca peluang, (b) kepercayaan diri yang tinggi, (c) pemanfaatan informasi, unsur kepercayaan diri yang tinggi memiliki nilai tertinggi dengan persentase sebesar $84,4 \%$. nilai tertinggi diperoleh dimensi kepercayaan diri yang tinggi dengan persentase sebesar $84,4 \%$ yang memiliki tiga indikator yaitu a) yakin dengan kemampuan sendiri, (b) tidak bergantung pada orang lain, (c) tidak mudah putus asa. Artinya semakin tinggi tingkat kepercayaan diri yang dimiliki para peternak dari yakin dengan kemampuan sendiri serta tidak mudah putus asa apabila mengalami kegagagalan, sehingga ke depannya produktivitas Peternaknya akan semakin meningkat. Dan paling rendah diperoleh dimensi pemanfaatan informasi dengan persentase sebesar $42,2 \%$.

\section{Hubungan Dinamika Kelompok dengan Produktivitas Peternak}

Antara dinamika kelompok dengan produktivitas peternak terdapat hubungan nyata dengan nilai signifikansi $<0,01$ yaitu sebesar 0,000 yang berarti semakin tinggi dinamika kelompok maka semakin tinggi produktivitas peternak, dilihat dari kedinamisan yang ada dalam kelompok, seperti memiliki kesamaan tujuan, struktur yang ada di dalam kelompok jelas, peran kelompok berfungsi dengan baik bagi anggota, dan suasana kelompok nyaman bisa merangsang peternak untuk meningkatkan produktivitasnya.

\section{Hubungan Unsur-unsur Dinamika Kelompok dengan Produktivitas Peternak}

Antara tujuan kelompok dengan produktivitas peternak terdapat hubungan nyata dengan nilai signifikansi $<0,01$ yaitu sebesar 0,000 yang berarti apabila tujuan dalam kelompok memiliki kesamaan serta tidak terdapat tujuan yang bertentangan dalam kelompok yang bisa membuat ketidakharmonisan hubungan dalam kelompok dapat meningkatkan produktivitas peternak.

Keberadaan struktur kelompok sangat penting dalam mencapai keberhasilan kelompok.struktur kelompok dengan produktivitas peternak berhubungan nyata dengan nilai signifikansi $<0,01$ yaitu sebesar 0,000 . Dimana dengan adanya struktur kelompok yang jelas membuat kelompok jauh lebih terarah serta terjalin hubungan yang baik dalam kelompok dapat menentukan produktivitas peternak menjadi lebih baik.

\section{Produktivitas Usaha Ternak}

Produktivitas peternak secara tidak langsung memiliki hubungan dengan produktivitas usaha ternak, namun untuk mengukur produktivitas usaha ternak yang terdapat dilapangan sangat sulit dikarenakan objek yang diteliti sangat beragam, salah satunya dari lama bergabung responden yang berbedabeda, ada responden yang baru mulai bergabung ke dalam Paguyuban selama 3 tahun, ada yang bergabung selama 5 
tahun, dan ada yang sudah bergabung selama 7 tahun, dan juga ternak yang dimiliki peternak yang beragam, ada yang hanya memiliki indukan saja, indukan dan anakan yang masih kecil, dan ada juga yang memiliki ternak yang sudah siap untuk dijual, akan tetapi hanya sebagian peternak saja yang sudah memiliki ternak yang sudah siap untuk dijual. Untuk itu penulis hanya meneliti hubungan dinamika kelompok dengan produktivitas peternaknya, dikarenakan keberagaman akan jumlah ternak yang dimiliki dan lama bergabung dari masing-masing peternak yang tidak serentak.

\section{KESIMPULAN DAN SARAN}

\section{Kesimpulan}

1. Dinamika kelompok termasuk dalam kategori tinggi. Yang terdiri dari beberapa indikator, antara lain: tujuan kelompok, struktur kelompok, fungsi tugas kelompok, pengembangan dan pemeliharaan kelompok, suasana kelompok, dan tekanan kelompok. Dari enam indikator dinamika kelompok, indikator suasana kelompok menduduki penilaian tertinggi yaitu sebesar $95,6 \%$, hal ini dikarenakan semakin baik atau nyaman suasana dalam kelompok, baik dari segi hubungan antar anggota, kebebasan berpartisipasi maupun lingkungan fisiknya, maka tingkat kedinamisan kelompok akan semakin tinggi. Dan terendah yaitu indikator tekanan kelompok.

2. Produktivitas peternak termasuk dalam kategori tinggi. Yang terdiri dari beberapa kategori, antara lain: kemampuan membaca peluang, kepercayaan yang tinggi, dan pemanfaatan informasi. Dari tiga indikator produktivitas peternak, indikator kepercayaan diri yang tinggi menduduki penilaian tertinggi yaitu sebesar 84,4\%. Hal ini dikarenakan semakin tinggi tingkat kepercayaan diri yang dimiliki para peternak, maka produktivitas peternaknya akan meningkat.

3. Dinamika kelompok dengan produktivitas peternak terdapat hubungan nyata dengan nilai signifikansi $<0,01$ yaitu sebesar 0,000 yang berarti semakintinggi dinamika kelompok maka semakin tinggi produktivitas peternak, dengan keterangan kesemua unsur yang terdapat pada dinamika kelompok memiliki hubungan signifikan dengan produktivitas peternak.

\section{Saran}

Berdasarkan hasil penelitian, saran yang akan diberikan adalah sebagai berikut :

1. Tekanan kelompok perlu ditingkatkan lagi, baik berupa pemberian sanksi bagi anggota yang melanggar aturan, penghargaan bagi para anggotanya yang berprestasi, agar kedepannya tingkat kedinamisan kelompok bisa lebih baik lagi.

2. Kemampuan dalam membaca peluang masing-masing anggota perlu dibimbing dan ditingkatkan lagi, agar kedepannya bagi anggota yang kurang mampu melihat peluang dalam mengembangkan usaha ternak bisa teratasi, sehingga produktivitas peternaknya bisa lebih meningkat.

3. Hubungan kekeluargaan antar anggota perlu dijaga, agar 
kedinamisan kelompok tetap terjaga sehingga membuat para anggota bergairah dalam meningkatkan ternak yang dimiliki.

* Alamat Korespondensi:

ujang.maman@uinjkt.ac.id 
Jurnal Agribisnis, Vol. 12, No. 1, Juni 2018, [75 - 85]

ISSN : 1979-0058 